\title{
THEORETICAL GUIDELINES FOR THE UTILIZATION OF INSTRUCTIONAL SOCIAL NETWORKING WEBSITES
}

\author{
Assist. Prof. Dr. Ilker YAKIN \\ Faculty of Education, Mersin University \\ Mersin, TURKEY \\ Assist. Prof. Dr. Hasan TINMAZ \\ Faculty of Engineering and Architecture, Gelisim University \\ Istanbul, TURKEY
}

\begin{abstract}
In the past 10 years, the internet has been transformed, along with the emergence of interaction and communication technologies. Indeed, there has been an emerging movement in the interaction and communication technologies. More specifically, the growth of Web 2.0 technologies has acted as a catalyst for change in the disciplines of education. The social networking websites have gained popularity in recent years; therefore, many research studies have been conducted to explain how the use of social networking websites for instructional purposes. For the best practices, it is essential to understand theories associated with social networking studies because related theories for any subject may provide insights and guideline for professionals and researchers. This theoretical paper was designed to offer a road map through the literature in relation to the utilization of social networking websites by presenting main understandings of theories associated with social networking.
\end{abstract}

The Uses and Gratification Theory, social network theory, connectives, and constructivism were selected to serve as a basis for designing social networking studies regarding instructional purposes. Moreover, common attributes of the theories and specific application areas were also discussed.

This paper contributes to this emerging movement by explaining the role of these theories for researchers and practitioners to find ways to beneficially integrate them into their future research endeavors.

Keywords: Social Networking Sites, Web 2.0, Uses and Gratification Theory, Social Network Theory, Connectivism, Constructivism.

\section{INTRUDUCTION}

Technological developments are reshaping our lives. Modern time computer users have a tendency to access all kinds of information at anytime and anywhere. Therefore, services offering more data with less effort seem highly preferable (Johnson, Smith, Levine \& Haywood, 2010). Besides, as computer and information technologies are maintaining their developments, their roles within society will increase more and more (Boogart, 2006). In parallel, our century is getting highly integrated and networked in terms of human interaction and communication.

The history of technological changes is an overt reflection of how the Internet has altered our methods of communication. Especially after the 1990s, with the explosion of 
computer-mediated communication tools, the Internet has become one of the most popular ways of interaction (Vitak, 2008). Additionally, we realize that no other generation has been more imposed to the technological innovations than ever before (Andon, 2007). Nowadays nearly all college students depend on technological tools for their daily lives. Hence the use of the Internet is increasing among the young. Within this framework, it is clear that we need scientific studies on how this technology-inflated era influences our social features. These technology and socialization oriented studies must respond to the questions of how people interact with each other via technologies (Andon, 2007).

Over the past decade, there has been an emerging movement in the interaction and communication technologies. In fact, they have shaped all aspects of the day-to-day events (Williams, Karousou, \& Mackness, 2011). Indeed, the growth of Web 2.0 technologies has acted as a catalyst for change in the disciplines of education. Researchers and professionals try to understand the learning process in these evolving technologies. Especially, knowledge creation and sharing via Web 2.0 services have gained importance so as to distribute ideas and creative works and products (Bell, 2011). Therefore, these advances in Web 2.0 technologies have been tried to be used for improving the learner's experience, most notably collaboration and communication (Kop \& Hill, 2008). According to Siemens and Tittenberger (2009), there are four factors of transforming prospective educational activities; global, social/political, technological and educational. The latest technological developments have already transformed the learning and socialization process of new generations. Social networking sites considered as social media technologies have become trustworthy programs for sharing information among users in a timely fashion (Osatuyi, 2013).

In general terms, theories try to find out whether their hypothesis and rules work in a specified practice area. That is why they are valuable for the researchers to explain many things occurred with specific settings or people. According to Snelbecker's (1999) definition, a theory is "an organized set of propositions that are syntactically and semantically integrated and that serve as a means of predicting and explaining observable phenomena" (p.33). Although the term theory has been used in different ways in the instructional phenomena, it can be considered as "a set of statements that take the form conditions-model-outcomes, just as a principle that takes the form conditionsmethod-outcome" (Reigeluth, 1983, p. 21). Therefore, related theories may provide insights and road maps for professionals and researchers conducting studies. This tenet can also be applicable for the studies related to social networking websites regarding instructional purposes.

In the immense scientific literature, there are many theories associated with social networking. The application of Uses and Gratification Theory (U\&G), Social Network Theory (SNT), Connectivism, and Constructivism theories in the study of Web 2.0 technologies have received a great amount of attention from researchers. This paper has been designed to offer a road map through the literature in relation to the utilization of social networking websites as well as providing a framework for considering that literature. Most scholars and practitioners who read this paper will be able to find ways to beneficially integrate U\&G, SNT, Connectivism, Constructivism and analysis into their future research endeavors.

\section{USES AND GRATIFICATION THEORY (U\&G THEORY)}

The uses and gratification theory (U\&G) was developed by the functionalist theorists such as Jay Blumler and Elihu Katz (Siraj, 2007).

Many concepts and labels have been used to explain U\&G; to illustrate, a media use paradigm (Luo, Chea, \& Chen, 2011), a theoretical framework (Smock, Ellison, Lampe, \& Wohn, 2011), a psychological communication perspective, and an axiomatic theory (Ko, 
Cho, \& Roberts, 2005). The U\&G is based on the premise that media can affect people if they have some use for those tools or their messages to being transmitted (Mondi, Woods, \& Rafi, 2008). Beginning with the 1940s, researchers tried to understand why users were involved in different forms of media (Ruggiero, 2000). In general, U\&G has been used for investigating how traditional media and social media are utilized to satisfy the needs of users with different aims (Ko et al., 2005; Smock et al., 2011). Therefore, it is possible to assert that U\&G can be used as a framework for the research studies dealing with the study of Internet and new media communication (Ruggiero, 2000).

The history of the uses and gratification researches goes back to the first mass communication devices. As a sub-tradition of media effects research, U\&G has been grounded on the approach pointing out the attractions and gratifications while audiences deal with the media, and their social and psychological needs (Ruggiero, 2000). The audiences of communication process have certain needs; which sometimes could be defined by Maslow's hierarchy of needs theory. In order to fulfill these needs, audiences, as active participants in the process, utilize tools and perceive a certain level of gratification or dismay. The scientific approach which conducts studies on the audiences about the usage processes and feeling regarding to these context is basically called as the uses and gratification research (Katz, Blumler, \& Gurevitch, 1974).

Basically, the uses and gratification approach deals with the reality that different users of the same communication tool might have different reasons for using it (Severin \& Tankard, 1997). U\&G focuses on scientific explanations of how people use any communication tool to fulfill their personal needs. Through a scientific scrutiny, scholars reveal the possible advantages and disadvantages of utilization of any communication tools (Nyland \& Near, 2007). In that sense, a vital part of U\&G is users' activities and their motivations which are the key factors of personal utilization of the tools (Luo et al., 2011).

Furthermore, U\&G concentrates on what sources of motivation people use the tools and what satisfaction people experience from their utilization. Gratification issues can be categorized as content satisfaction dealing with what a tool offers and process satisfaction relating to what experiences the tool offers (Joinson, 2008). While people are actively participating into online communities, they demand certain gratifications, values and benefits from the communities. Hence, how people's characteristics affect their gratifications is an essential scientific pursuit (Farfaglia, et al., 2006).

The fundamental contribution of U\&G is its remarks on active consumers and audiences in the context of communication (Nyland \& Near, 2007). U\&G approach might be utilized to investigate baseline questions about gratifications for using social media (Smock al., 2011). The uses and gratification research is important for commercial purposes as well, since the producers want to offer most satisfactory tools for communication to the society (Severin \& Tankard, 1997). Therefore, it can be inferred that exploring customers' adoption decision might be simplified by U\&G with offering a new approach (Luo et al., 2011).

The uses and gratification research is typically based on survey research design. Effective uses and gratification research must stem from or get support of the following disciplines as much as possible; psychology, sociology, philosophy, linguistics, computer sciences, and research methods (Severin \& Tankard, 1997). More specifically, the experimental or quasi-experimental traditions dominated the media effects researches in the past by manipulating the conditions (Ruggiero, 2000).

To conduct a more interpretive media research, qualitative methodologies should also be employed in a holistic approach (Ruggiero, 2000). Therefore, social and cognitive terminologies could be utilized for media's uses and gratifications studies (LaRose \& Eastin, 2004). 
The uses and gratification approach is also crucial for understanding new descriptive variables in relation to new media and its new gratifications. In general, individuals' choices regarding the adoption of information technology depend on the motivational factors directed by their needs (Luo et al., 2011). For instance; the habit strength is a good variable in the uses and gratifications studies. Besides, gratifications should be defined as expected outcomes (LaRose \& Eastin, 2004). More specifically, Luo et al. (2011) categorized the users' motivations of technology use into intrinsic (undertaking an action or an operation out of pleasure and satisfaction) and extrinsic (undertaking an action or an operation to acquire something outside the function). Likewise, the quality of the system is a significant predictor for members' gratifications and the underlying reason of intentions for using the system (Lin \& Lee, 2006). It is widely supposed that users decide and use suitable media for gratifying their conscious needs (Ko et al., 2005).

The content of the media, the ways of interaction with media and the social framework of using the media are the different vital causes of users' gratifications on communication (Katz, Blumler, \& Gurevitch, 1974). Precision on information, whenever and wherever there is an access opportunity for information, the value of information and the different types of customizable information define the quality of the information which is a significant indicator of the member satisfaction in an online community (Lin \& Lee, 2006). U\&G provides researchers with extensive beneficial opportunities in terms of a better interpretation of users' actions, outcomes and comprehension while they are involved with media (Smock et al., 2011).

Considering a social networking website, designers must remember that different people utilize these websites in totally different ways and different people perceive different satisfaction from those websites. Because different users utilize social network sites such as Facebook for different aims, these reasons might be linked to different types of use (Smock et al., 2011). To illustrate, "convenience, information seeking, interpersonal utility, pass time, entertainment, escapism, peer identity, and social interaction" (Luo et al., 2011, p. 22) are the main motivational factors of the internet utilization. To comprehend individuals' motivational factors concerning the utilization to traditional media and the internet, U\&G theory might be a very useful approach (Luo et al., 2011). In other words, U\&G can be employed to different conditions and cases, most notably virtually to every kind of mediated communication tools (Ko et al., 2005). In order to make headway, it is important to validate the results obtained from recent studies with regard to traditional media and the internet utilization. It is important to realize that the model provides U\&G theorists with a theoretical perspective when they try to understand the role of new communication tools and technologies (Siraj, 2007). However, as Mondi et al. (2008) stated, there is a need to study the users' motivations for e-electronic media in instructional purposes. Therefore, researchers must conduct studies on understanding different uses and gratifications of social networking websites. To conclude, the traditional model of U\&G might provide the necessary guidelines for researchers to investigate the use of both the internet and the new media communication (Luo et al., 2011).

\section{SOCIAL NETWORK THEORY (SNT)}

The Social Network Theory (SNT) as an area of work or study in the fields of social sciences deals with modeling the complex relationships between people (Yang, Yang, Zhang, \& Spyrou, 2010) and relates to human communities varying between small numbers of individuals to the whole population (Ethier, 2006). Beginning with the early 1930s, SNT has evolved mainly from psychology, anthropology, and mathematics (Hatala, 2006). These days, researchers have utilized SNT and its concepts as a promising research approach in different branches and fields (Quatman \& Chelladurai, 2008). 
The word "network" appeared initially for the career advancement contacts in the 1970s. Afterwards, network has started to refer to the television. Computer systems adopted this term from the television in parallel with their formation. Nonetheless, the term "network" has already been adapted into social sciences for decades referring to mapping human relationships (Rosen, 2007). Siemens (2004) describes a network "as a connection between entities" (p.4). A set of objects (nodes) and a mapping or description of relations between these objects is the main elements of a network (Kadushin, 2004). As for Ethier's (2006) definition, network is "a set of objects, or nodes, and a mapping or description of the relationship between the objects" (p.1). He continues by saying that in the event of social networks, people or groups of people are considered as objects.

An approach of describing the everyday practices of social interaction occurring in the communities could be definition of the social networking (Merchant, 2012). Moreover, a social network is the ultimate aim of establishing an incorporated whole by connecting different people. Social networking studies have been triggered by the following question; 'if there were a set of $\mathrm{N}$ people, what would the probability of each member among $N$ people connected to another member via $k \_1, k \_2, k \_3 . . . k \_n$ links' be. Social psychologist, Stanley Milgram, answered this research question by an empirical research study called "Small World Experiment" (Kelty, 2005). Milgram calculated the average number of connections as $\mathbf{5 . 5}$ where this number became an expression in the following years as "six degrees of separation" also known as "human web". Basically, the concept refers to the power of established connections on a small world where people must take advantage of these connections (Rosen, 2007). In other words, individuals and their relationships as nodes of graph and edges of the graph respectively are displayed by SNT (Madey, Freeh, \& Tynan, 2002).

In general, SNT is employed by the researchers to investigate the mappings linking one person to the others so as to assess the social capital of that person (Ethier, 2006). The concept of social capital is the most popular connection and notable applications of SNT (Hatala, 2006; Quatman \& Chelladurai, 2008). Social capital, the number of friends a person has on a social network, is also important for online communities. As the personal and social capital increase, active participation and trust to the online community increases (Ellison, Steinfield, \& Lampe, 2007). To illustrate, the number of friends for Facebook members is a strong indicator of belongingness to an online community. In other words, the individual might manage more knowledge, influence and power if that individual has more connections and mappings in his/her social network (Ethier, 2006).

In the last decade, the network concept is extended toward social networking. Social networks, in general, have existed since the time of the first human beings where social relationship was established (Coyle \& Vaughn, 2008). Although social networking websites are well known in the society, the term "social networking" is ambiguous for the users. The concept of "social network" is not easy to describe, since there are many different examples in its current use (Lange, 2007).

There are many ways in which people could socialize and create networks in their lives. With the latest developments of Internet and related tools, real life has transferred to online settings (Hinduja \& Patchin, 2008). Therefore, it is possible to claim that social networking might be described as a new paradigm which enables researchers to improve and alter pre-existing relations (Merchant, 2012). These characteristics may lead to the fact that social networks as a research topic can be utilized in many different fields (Ethier, 2006).

There is a slightly important difference between a community and a network. A community is organized around an interest with shared and joint manners, whereas a network is organized around individuals (Dalsgaard, 2008). In that sense, the community structure forms the most illustrative characteristics of social networks (Yang et al., 2010). With the latest developments in technology, it was observed that people start to be 
competent as a result of their established contacts with other people. Thus, networks have become the most essential learning elements of the modern era (Marhan, 2006). Besides, networks could work like a filtering mechanism in the information creation process (Siemens \& Tittenberger, 2009). In doing so, people have a chance to create more social connections within their communities than the people who belong to other communities (Yang et al., 2010).

With the highly complicated modern life, individuals cannot be held the entire processes of any activity. Hence, we ought to distribute the complex tasks dealt with into different entities (Siemens, 2006). Later, we can connect these different entities to each other in order to form a network. For example, learning, as an active process, should be networked among instructors and learners. Moreover, interactions among learning networks must be provided with an effective information acquisition (Palloff \& Pratt, 2007).

For Storsul et al. (2008), social networking resembles to four human daily activities; meeting at a café, taking part in a festival, playing games in a park, and spending time in a big shopping center. Storsul et al. (2008) states that the motives for attending these four activities explain the reasons of people's attention on using social networking during the last decades. With using the principles of SNT, many particular connections and relations such as communication, instrumental, power, and interpersonal can be estimated within the studied group of people (Hatala, 2006).

Next Thing Now Report (2008) highlights an essential point: "They [Social Networks] are aiming to be the one-stop shop for all your Internet needs. Consequently, we are spending more time with them and doing more on them" (p.34). Basically, social networks manage people's political participation; to illustrate, corporate action, voting preferences and other methods of these participations are the examples of behavior (Ethier, 2006). New generations use technologies mainly with social networking purposes, such as expressing their ideas and feelings, meeting new people and understanding different cultures and groups (Oblinger, \& Oblinger, 2005). Donath (2008) remarks that it is too early to tell whether social networking has reshaped our current societies. Yet, new generations spend more time online than offline for communicating with their friends.

Online social networking assists people in creating communities of practice on shared interests (Huang, Yang, Huang \& Hsiao, 2010). Corporate activity arises in the event of a positive correlation between interest and power in terms of participation and contribution occurring in a network (Ethier, 2006). To illustrate, social networking has begun as a critical decision maker for friendships, even as re-defining the concept of the friendship and its role on society (Beer, 2008).

In the last decade, social interaction via the Internet has become more fashionable among users. Basically, users use the internet so as to communicate with each other in a channel of connected social networks (Merchant, 2012). This situation leads more interest to social networking web sites from the perspective of users, researchers, and practitioners (Sachdev, 2007). Web 2.0 technologies have led to social networking in which our communication methods are altered from their basic dynamics. That is why it is a beneficial endeavor to realize the Web $\mathbf{2 . 0}$ framework for a better understanding of online social networking.

Web 2.0 context stresses out the social character of the Internet technologies which are also called as social software (Vie, 2007). Sachdev (2007) notes that more recent social networking web sites such as MySpace and Facebook, triggered interest in the Internet where users spend more time than the others. Communication could be encouraged by the social networks on the Internet. People create communities of people with whom they experience a common point or interest (Medina, 2007). Medina talks about the 
virtual communities as special locations on the Internet where the users come together to share information in a large variety of issues and concerns. The SNT and network analysis provide a broad range of subject topics to be studied. As Borgatti, Mehra, Brass, and Labianca (2009) point out that similarities (location, membership, attribute), social relations (kinship, roles, affective, cognitive), and interactions constitute a typology of ties studies in social network analysis.

Social networking web sites are offering connection methods for socialization (Vitak, 2008). Although social networking websites are characterized as a revolution in the human communication, it is better to describe social networking websites as the evolutionary structure of communication with innovative technologies (Coyle \& Vaughn, 2008). That is why researchers have studied different types of networks such as the Internet and the World Wide Web in the communities in the recent years (Musolesi \& Mascolo, 2007).

A social networking profile is always altering the dynamics of social interactions. For instance, tagging people in Facebook profiles or a simultaneous update in News Feed of Facebook are simple examples of continuous dynamism in the profiles (Tufekci, 2008). By posting different things to their profiles, teens establish their online identities in different social networking sites. The research has demonstrated that older teens upload more information to their profiles than younger teens. Moreover, the privacy issue is strongly related with the gender of the users (Lenhart \& Madden, 2007).

It is possible to answer a diverse range of theoretical, methodological and philosophical questions via SNT (Quatman \& Chelladurai, 2008). Because the form and structure of the real social networks are interpreted with SNT (Yang et al., 2010), the scope of social network studies is the patterns of interactions and interrelationships among the network members. Basically, as Krause, Croft, and James (2007) point out that networks answer questions like "who is connected to whom in the population and by what relationship" (p.16). By studying the patterns, researchers deal with communication, group dynamics, social roles on the network, gratifications of the members and the way of sharing resources (Todd, 2008).

Although education has been one of the fields in which SNT theories and concepts have been widely used (Quatman \& Chelladurai, 2008), studies incorporating SNT and the analysis should be investigated regarding implementations in social networking websites' utilization in many different situations and cases.

\section{CONNECTIVISM}

Connectivisim has been labeled as a learning theory in the information and digital age of the networked era (Al-Shehri, 2011; Anderson \& Dron, 2011; Boitshwarelo, 2011). In other words, it tries to rationalize how the new learning technologies affect learning (Marhan, 2006). In the literature, the recognized gurus on the connectivism are George Simens and Stephen Downes (Al-Shehri, 2011; Boitshwarelo, 2011; Kop, 2011). Although the theory has not been widely accepted (Tschofen \& Mackness, 2012), informal, connection-based, and network creating learning environments replace of formal and rigid learning settings (Siemens, 2005).

The principles of chaos, network and complexity, and self-organization theories formed the bases of the connectivism (Marhan, 2006; Siemens, 2006).

Siemens (2004) emphasizes that in parallel to significant changes in human lives, learning theories reflected in instructional activities must be renewed as well. Siemens remarks that learning theorists must take social aspects and networking issues into consideration for better understand the current learners. Traditional theories such as behaviorism, cognitivism, and constructivism, were the dominant in an era directed by 
rapid knowledge development. However, these days, networking technologies are playing an instrumental role in the science of learning (Siemens, 2006). Because connectivism depends on the premise that preceding theories have some limitations to explain certain complexities of the learning processes (Siemens, 2004), it provides a practical paradigm to fulfill the gaps that its predecessors could not address. To illustrate, these theories have dealt with the individual side of the learning. More specifically, as Siemens (2005) asserts learning occurring outside people has not been addressed by preceding theories. These days, the predominant position in educational science proposes distributing much of the knowledge through networks of people instead of holding it in the mind of individuals (Siemens, 2006). Secondly, the challenges of organizational knowledge and transference are still needed to be explored by these theories (Siemens, 2004).

One of the major differences between Connectivism and other theories is that "learning can reside in non-human appliances" (Kop \& Hill, 2008, p.7; Siemens, 2005, p. 23). From the point of view of the connectivists, it is convenient to define learning as "a process of building networks of information, contacts, and resources that applies to real problems" (Anderson \& Dron, 2011, p.87). The second major focus considered as a key difference is that connectivits give a lot of attention to the networked and shared experiences (Tschofen \& Mackness, 2012). That is why exploration, inquiry, decision making, selecting, and deselecting processes are considered as preparatory and vital activities for the learning experience (Siemens, 2006). In that sense, it is possible to conclude that two critical concepts, knowledge creation and a networked process, play a more prominent role in building a theory.

Firstly, it is a tenet of connectivism that knowledge as a stream of information is transmitted through networks of human and non-human channels (Al-Shehri, 2011). Socialization, new technologies, the power of the connections, and the context of occurrence affect, help, and improve learning in connectivism (Tschofen \& Mackness, 2012). Therefore, information is articulated and benefited by people in a learning community (Boitshwarelo, 2011). In that sense, learning can be defined as outlining connections between different pieces of data so as to create an entire comprehension of the subject (Marhan, 2006). In other words, connectivits assert that people do not learn in a single environment, or rather, knowledge is transmitted through the Web; therefore, individuals' active participation constitutes learning (Kop, 2011). Thus, helping learners to form networks and enabling them to elicit a sense of self-efficacy in network-based cognitive skills are one of the main tasks of the connectivist pedagogy (Anderson \& Dron, 2011).

Secondly, knowledge is disseminated through an information network or community rather than constructed or created in the minds of individual (Boitshwarelo, 2011; Kop \& Hill, 2008). In that sense, learning can be defined as a networked process in which individuals combine external contents with a holistic representation (Marhan, 2006). The cycle of knowledge development takes place into these communities in order to enable individuals to learn (Marhan, 2006). That is why learning is considered as a network creation process in the connectivist approach (Marhan, 2006). Therefore, learning embodies in the active participation of individuals in a network with other people instead of transferring knowledge from teachers or educators to the learners (Kop, 2011).

In doing so, the learners' navigation of the information skills is given prominence to the construction of information organization and presentation rather than presenting only the knowledge or information (Siemens, 2005).

As Boitshwarelo (2011) claims that connectivist learning environments are complex in nature because of the two reasons. Firstly, these environments comprise networks of individuals. This feature is also cited by Kop and Hill (2008) that the network or communities do not need to be only online only. Indeed, connectivism offers that theory encompasses a larger learning environment in which it enables people to understand the 
world and how they learn (Kop \& Hill, 2008). Secondly, individuals' continuous engagement is needed to sustain the dynamic nature of the communities (Boitshwarelo, 2011). This feature provides a continual process (Marhan, 2006). Therefore, it is possible to assert that memorizing and even understanding everything might not be considered as the learners' roles, or rather, they should have a greater capacity for finding and utilizing the information whenever needed (Anderson \& Dron, 2011).

Online environment and learning communities are vital as a vehicle in the development and simplification of the connectivism (Boitshwarelo, 2011). These learning communities are described as a node by connectivits (Kop \& Hill, 2008). In that network, producing, conserving and using the information flow should play an instrumental learning activity (Marhan, 2006). In doing so, social networking websites provide some major types of learning activities as proposed and seen as vital to learning by connectivits (Kop, 2011). To illustrate, learners have a chance to create something of their own or they can share their products with others on the network. In general terms, communication, socialization and participation in shared interests can be seen as important needs fulfilled via Web $\mathbf{2 . 0}$ technologies (Tinmaz, 2012).

Advances in Web 2.0 services and mobile technologies have dramatically altered the educational practices, most notably, new and particular educational structures and organizations (Kop \& Hill, 2008). Building a network for reaching knowledge and information via connecting each other whenever needed is provided throughout Web 2.0 technologies (Tinmaz, 2012). As Siemens (2005) points out that many collaborative platforms allow the learners to reach and use information sources for building their own learning process in a way that learning content, knowledge and information are not presented in a linear sequential method. Therefore, the links and connections embedded in the network are created by the learners, not by the teachers or educators. It is apparent that most of the hypotheses and propositions are still needed to be investigated through scientific researches.

\section{CONSTRUCTIVISM}

It is obvious that not only the ontological and epistemological conception of the learning but also the features of the instructional activities have altered with a great amount of attention given to the constructivist assumptions. Jonassen, Cernusca, and Lonas (2007) articulate that constructivism has been considered as both a theory of learning and an epistemological and ontological understanding of "what reality, knowledge, the mind and, thought, and meaning are" (p.46). Although Piaget's and his followers' theories and understandings regarding the personal constriction of knowledge have led researchers to build basic assumptions of the constructivism, the roots of the constructivist approaches have depended on the work of Vygotsky and Dewey (Anderson \& Dron, 2011).

Social constructivism broad category of these preceding efforts has come into prominence. It is a tenet of constructivism that "social nature of knowledge and its creation in the minds of individual learners" (Anderson \& Dron, 2011) can be considered as main philosophical approaches of the theory.

Social-constructivists claim that individuals and social groups construct a reality in a way that their experiences and interpretations make the meaning of the world (Jonassen et al., 2007). Therefore, active engagement and interaction with other people may be the best effective strategies for learning (Anderson \& Dron, 2011). As a well-known psychologist, Vygotsky highlights the importance of social interactions in the learning process, especially for cognitive development. Vygotsky notifies that sharing different experiences among learners will stimulate the cognitive development process. Vygotsky utters that in the early childhood, people develop basic communication skills in the form of aural and visual means. Afterwards, people take advantage of these means for fulfilling their social interaction needs. As people get satisfied with the social interaction needs, 
these needs yield higher order thinking skills (Learning Theories Knowledgebase, 2011). Therefore, it is highly essential for learners to have a social interaction context for creating effective learning outputs.

Although there are different types of constructivism proposed by different theorists, most of the theories and approaches share common understandings of the epistemological beliefs and pedagogical perspectives. To illustrate, knowledge is constructed by individuals in the community of practice form one of the basis of these commonalities (Kang, Choi, \& Chang, 2007). Lave and Wenger (1991) coined to the term communities of practice (COP) so as to capture the importance of activity in binding individuals to communities and of communities to legitimizing individual practice. Barab and Duffy (2000) noted that "the term more commonly used is situated, reflecting the key proposal from both the constructivist and situativity theories that knowledge is situated through experience" (p.25). According to the this approach, situative perspectives, interactions with the world are viewed as not only producing meanings about social world but also producing identities; that is, individuals are fundamentally constituted through their relations with the world (Barab \& Duffy, 2000). In general, it is possible to claim that individuals' understandings are constructed in their environments or communities.

As Graven (2004) stated, learning is not located in the acquisition of structure or in the heads of individuals but in the process of co-participation and the increased access of learners to participation. Therefore, forming and building communities are so important that the level and the strength of social interactions are the key elements of deciding the achievement or collapse of an online community. As Muijs, West, and Ainscow (2011) state that organizations might be effective providing that learners form communities of practice in networks and participate in a process of social learning.

The education sector has come across with several online instruction efforts, particularly over the last decade. In parallel with these efforts, researchers have begun discussions on issues regarding online communities occurring in those online instructional activities. It was unfolded that for the creation of online communities, members must have a profound desire and online interactions among other members (Liu, Magjuka, Bonk \& Lee, 2007). Although the history of online social networking goes back to the establishment of the Internet, there were computer networks which created the idea of computer-based communities (Acquisti \& Gross, 2006).

There is no consensus on describing online communities (Wise, Hamman \& Thorson, 2006). Even though different online communities want to accomplish different objectives, the basic premise is to create and maintain connections among other community members (Lampe, Ellison, \& Steinfield, 2007). In online communities; members freely join the community with their own willingness, they trust the other community members, and the management of the community (Marhan, 2006). In that sense, the establishment of online learning communities has two dimensions; technical and social (Liu, Magjuka, Bonk \& Lee, 2007). Hence, the construction of an online community is a difficult task for instructors.

It requires interaction and collaboration among learners in which instructors offer team work for learners (Palloff \& Pratt, 2007). For example; Liu et al. (2007) summarizes that instructors mostly prefer to offer asynchronous discussions to facilitate online discussions with its time flexible opportunity, more learner-centered design, and more time for elaboration on the ideas stated on the boards.

Our current generations have been tending to create online communities and social networks in different forms; physically attached, totally online or hybrid (Oblinger, \& Oblinger, 2005). In this way, there are different points of view in terms of categorization of online communities. For instance; Marhan (2006) specifies three forms of online communities in relation to connection types; 
$>$ one-to-one connected online communities (for instance, email tool),

$>$ one-to-many connected online communities (e.g., blogging tool), and

$>$ many-to-many linked online communities (e.g., wiki tool).

With the advancement of innovative and seductive Internet technologies, such as blogs, wikis, and social networking websites, educational stakeholders become more ambitious for discovering their roles on students' participation in instructional processes, basically their learning processes (Ellison \& Wu, 2008). Because, learners are no longer absorbers of knowledge in the context. Learners are more active in creating, disseminating and evaluating knowledge where these processes are getting faster with the technological innovations (Marhan, 2006). While students are in the learning process, they must also maintain their human roles in terms of connections with other students, instructors and other people (Palloff \& Pratt, 2007).

As the users interact more with the Internet, the impact of online communities have started to be a major challenge for all business sectors including education (Lin \& Lee, 2006). The structure of online communities has evolved since the establishment of social networking websites. Social networking websites are developed around the people and not around their interest as it was the case with online communities. In other words, social networks take the person into the center and knit the networks around this egocentric configuration (Boyd \& Ellison, 2007). Through personal profiles on Facebook, like the other social networking websites, members can create or contribute to online communities (Koening, 2008). Learning should afford opportunities for individual participation where knowledge must stem from practice with other people (Oblinger \& Oblinger, 2005). Online technologies provide several opportunities for active participation in social learning actions.

\section{CONCLUSIONS}

Although theories offer different tenets of applications with regard to social networking, it is possible to assert that they have close links. To illustrate, constructive philosophy of learning is consistent with U\&G in a way that constructivism highlights the idea that students' learning come about in case they are engaged in authentic tasks. This premise is consistent with U\&G's media and motivation paradigm (Smock et al., 2011).

Likewise, the constructivist organizational theory provides a basis for networking in a way that people having a common concern in the organizations create communities of practice in networks so as to share ideas, find solutions, and build innovations (Muijs et al., 2010). Moreover, social networking assists people in exchanging information with other network members. In established connections, members push each other for thinking further than what they could think on their own. In that sense, social networking works like Vygotsky's Zone of Proximal Development (ZPD) (Williams M., 2008).

Likewise, critical attributes are common to both Connectivism and social networking (AlShehri, 2011). To illustrate, the community is considered as a node (object) the main elements of a network (Boitshwarelo, 2011). Siemens (2005) asserts that "networked learning is a subset of connectivism" (p. 23). Indeed, he continues by saying that network forming as an attribute of the connectivism is strongly correlated with networked learning. Lastly, Constructivism and connectivism share also some core propositions; to illustrate; knowledge is not being acquired (Kop \& Hill, 2008). In that sense, the concept of online communities of practice as a fundamental approach for the constructivist perspectives of learning is one of the main arguments for expressing the connectivism (Boitshwarelo, 2011).

These four theories (Uses and Gratification Theory (U\&G), Social Network Theory (SNT), Connectivism and Constructivism) can serve as a basis for designing research studies associated with social networking. In other words, these theories provide blueprints for 
conducting researches by illustrating what or how to design and conduct social networking studies regarding instructional purposes.

\section{BIODATA and CONTACT ADDRESSES of the AUTHORS}

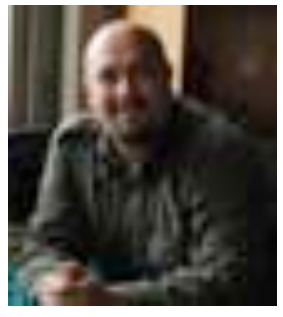

Dr. Ilker YAKIN is an assistant professor of computer education and instructional technology at Mersin University in Turkey. He received a Ph.D. in computer education and instructional technology from Middle East Technical University in 2012. His current areas of interest are human performance technology, social media in education, technology integration, design, development, and evaluation of learning and performance technology tools, electronic performance support systems, and pre-service teacher education.

Assist. Prof. Dr. Ilker YAKIN

Mersin University,

Yenisehir Kampusu, Faculty of Education;

Department of Computer Education and Instructional Technology,

33343 Yenisehir, Mersin, TURKEY

Tel: +90324 3412815 , internal: 1616

Fax: +90324341 2823

Email: yakinilker@gmail.com / ilker@mersin.edu.tr

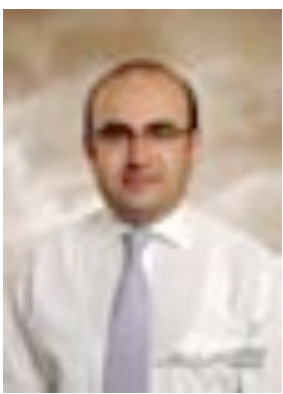

Dr. Hasan TINMAZ had his bachelor degree from Department of Computer Education, Faculty of Education, Middle East Technical University (2001). Then, he had completed his M. Sc. degree in Curriculum and Instruction Program, Department of Educational Sciences at Middle East Technical University (2004). He recently had his Ph.D. degree from Computer Education and Instructional Technology at Middle East Technical University (2011). Now, he is an Assist. Prof. Dr. of Faculty of Engineering and Architecture at Istanbul Gelisim University, Istanbul, Turkey. His research focuses on Web 2.0/Web 3.0 technologies, instructional design, and human \& computer interaction.

Assist. Prof. Dr. Hasan TINMAZ

Contact Details: Gelisim University, Cihangir mah.

Şehit Jandarma Komando Er Hakan Öner Sk. No:1

Faculty of Engineering and Architecture;

Department of Computer Engineering, Avcllari Istanbul, TURKEY

Tel: +902124227000 , internal: 236

Fax: +902124227401

Email: hasan_tinmaz@hotmail.com / htinmaz@gelisim.edu.tr

\section{REFERENCES}

Acquisti, A. \& Gross, R. (2006). Imagined communities: Awareness, information sharing, and privacy on the Facebook. PET 2006 - 6th Workshop on Privacy Enhancing

Technologies, Robinson College, Cambridge, United Kingdom. Retrieved May 19, 2010, from http://petworkshop.org/2006/preproc/ preproc_03.pdf

Al-Shehri, A. (2011). Connectivism: A new pathway for theorising and promoting mobile language learning. International Journal of Innovation and Leadership in the Teaching of Humanities, 1(2): 10-31.

Anderson, T., \& Dron, J. (2011). Three Generations of Distance Education Pedagogy. International Review of Research in Open and Distance Learning, 12(3), 80-97. 
Andon, S. P. (2007). Evaluating computer-mediated communication on the university campus: The impact of Facebook.com on the development of romantic relationships. Unpublished master's thesis, The Florida State University, Florida.

Arends, R. I. (2001). Learning to teach (5th Ed.). New York: McGraw Hill.

Barab, S. A., \& Duffy, T. (2000). From practice fields to communities of practice. In D. Jonassen \& S. M. Land (Eds.) Theoretical Foundations of Learning Environments, Mahwah, NJ: Lawrence Erlbaum, 25-56.

Beer, D. (2008). Social network(ing) sites... revisiting the story so far: A response to danah boyd \& Nicole Ellison. Journal of Computer-Mediated Communication, 13, 516-529.

Bell, F. (2011). Connectivism: Its place in theory-informed research and innovation in technology-enabled learning. International Review of Research in Open and Distance Learning, 12(3), 98-118.

Boitshwarelo, B. (2011). Proposing an integrated research framework for connectivism: Utilizing theoretical synergies. International Review of Research in Open and Distance Learning, 12(3), 161-179.

Boogart, M. R. V. (2006). Uncovering the social impacts of Facebook on a college campus. Unpublished master's thesis, Kansas State University, Manhattan, Kansas.

Borgatti, S., Mehra, A., Brass, D. J., \& Labianca, G. (2009). Network analysis in the social sciences. Science, 323, 892-895.

Boyd, D. M., \& Ellison, N. B. (2007). Social network sites: Definition, history, and scholarship. Journal of Computer-Mediated Communication, 13(1), Retrieved May 11, 2008 from http://jcmc.indiana.edu/vol13/issue1/boyd.ellison.html

Coyle, C. L. \& Vaughn, H. (2008). Social networking: Communication revolution or evolution?. Bell Labs Technical Journal, 13(2), 13-18.

Dalsgaard, C. (2008, June 24). Social networking sites: Transparency in online education. A paper presented in EUNIS 2008 VISION IT - Vision for IT in Higher Education. Århus: Denmark. Retrieved September 05, 2009, from http://eunis.dk/papers/p41.pdf

Donath, J. (2008). Signals in social supernets. Journal of Computer-Mediated Communication, 13, 231-251.

Ellison, N. B. \& Wu, Y. (2008). Blogging in the classroom: A preliminary exploration of student attitudes and impact on comprehension. Journal of Educational Multimedia and Hypermedia, 17(1), 99-122.

Ellison, N. B., Steinfield, C., \& Lampe, C. (2007). The benefits of Facebook "friends": Social capital and college students' use of online social network sites. Journal of ComputerMediated Communication, 12(4), 1143-1168.

Ethier, J. (2006, May 27). Current research in social network theory. Retrieved January, 27, 2013, from http://www.scribd.com/doc/11171859/Current-Research-in-SocialNetwork-Theory

Farfaglia, P. G., Dekkers, A., Sundararajan, B., Peters, L., \& Park, S.H. (2006). Multinational web uses and gratifications: Measuring the social impact of online community participation across national boundaries. Electron Commerce Res, 6, 75-101. 
Graven, M. (2004). Investigating mathematics teacher learning within an in-service community of practice: The centrality of confidence, Educational Studies in Mathematics, $57(2), 177-211$.

Hatala, J. P. (2006). Social network analysis in human resource development: A new methodology. Human Resource Development, 5(1), 45-71.

Hinduja, S. \& Patchin, J. W. (2008). Personal information of adolescents on the Internet: A quantitative content analysis of MySpace. Journal of Adolescence, 31, 125-146.

Huang, J. J. S., Yang, S. J. H., Huang, Y.-M. \& Hsiao, I. Y. T. (2010). Social learning networks: Build mobile learning networks based on collaborative services. Educational Technology \& Society, 13(3), 78-92.

Johnson, L., Smith, R., Levine, A., \& Haywood, K. (2010). 2010 Horizon report: K-12 Edition. Austin, Texas: The New Media Consortium.

Joinson, A. N. (2008). 'Looking at', 'looking up' or 'keeping up with' people? Motives and uses of Facebook. CHI 2008, Florence, Italy.

Jonassen, D., Cernusca, D., \& Ionas, G. (2007). Constructivism and instructional design: The emergence of the learning sciences and design research. In R. A. Reiser \& J. V. Dempsey (Eds.), Trends and issues in instructional design and technology (2nd ed.) (pp. 45-52). Upper Saddle River, NJ: Pearson.

Kadushin, C. (2004, February 17). Introduction to social network theory. Retrieved February, 4, 2013, from http:// hevra.haifa.ac.il/ soc/lecturers/talmud/files/521.pdf

Kang, I., Choi, J., \& Chang, K. (2007). Constructivist research in educational technology: A retrospective view and future prospects. Asia Pacific Education Review, 8(3), 397-412.

Katz, E., Blumler, J. G. \& Gurevitch, M. (1974).Uses and gratifications research. The Public Opinion Quarterly, 37(4), 509-523.

Kelty, C. (2005, June 9). Stanley Milgram's small world experiment. Retrieved April, 22, 2008, from http://cnx.org/content/m10833/2.2/

Ko, H., Cho, C., \& Roberts, M. S. (2005). Internet uses and gratifications. Journal of Advertising, 34(2), 57-70.

Koening, E. (2008). Creating identity in a digital age: The Facebook addiction. Retrieved July 21, 2010, from http://www.warren-wilson.edu/ socanth/students/ koenig08.doc

Kop, R. (2011). The challenges to connectivist learning on open online networks: Learning experiences during a massive open online course. International Review of Research in Open and Distance Learning, 12(3), 19-38.

Kop, R., \& Hill, A. (2008). Connectivism: Learning theory of the future or vestige of the past?. International Review of Research in Open and Distance Learning, 9(3), 1-13.

Krause, J., Croft, D. P., \& James, R. (2007). Social network theory in the behavioral sciences: Potential applications. Behavioral Ecology and Sociobiology, 62(1), 15-27.

Lampe, C., Ellison, N. \& Steinfield, C. (2007). A familiar Face(book): Profile elements as signals in an online social network. Proceedings of CSCW, San Diego, California, USA. 
Lange, P. G. (2007). Publicly private and privately public: Social networking on YouTube. Journal of Computer-Mediated Communication, 13(1), Retrieved September 25, 2009, from http://jcmc.indiana.edu/vol13/issue1/lange.html

LaRose, R. \& Eastin, M. S. (2004). A social cognitive theory of Internet uses and gratifications: Toward a new model of media attendance. Journal of Broadcasting \& Electronic Media, 48(3), 358-377.

Lave, J., \& Wenger, E. (1991). Situated learning: legitimate peripheral participation, Cambridge: Cambridge University Press.

Learning Theories Knowledgebase (2011, April). Social development theory (Vygotsky) at learning-theories.com. Retrieved March 19th, 2011 from http://www.learningtheories.com/vygotskys-social-learning-theory.html

Lenhart, A. \& Madden, M. (2007, April 18). How teens manage their online identities and personal information in the age of MySpace. Teens, Privacy \& Online Social Networks. Pew Internet \& American Life Project, Retrieved June 20, 2009, from http://www.pewtrusts.org/uploadedFiles/wwwpewtrustsorg/Reports/Society_and_the_ Internet/PIP_Teens_Privacy_SNS_Report_Final.pdf

Lin, H. F., \& Lee, G. G. (2006). Determinants of success for online communities: An empirical study. Behaviour \& Information Technology, 25(6), 479-488.

Liu, X., Magjuka, R. J., Bonk, C. J., \& Lee, S. (2007). Does sense of community matter? An examination of participants' perceptions of building learning communities in online courses. The Quarterly Review of Distance Education, 8(1), 9-24.

Luo, M. M., Chea, S., \& Chen, J. (2011). Web-based information service adoption: A comparison of the motivational model and the uses and gratifications theory. Decision Support Systems, 51(1), 21-30.

Madey, G., Freeh, V., \& Tynan, R. (2002). The open source software development phenomenon: An analysis based on social network theory. Eighth Americas Conference on Information Systems (pp.1806-1813). Dallas: The United States of America.

Marhan, A. (2006). Connectivism: Concepts and principles for emerging learning networks. The 1st International Conference on Virtual Learning, ICVL (pp. 209-216). Bucharest: Romania.

Medina, M. G. R. (2007). A look at the factors influencing the utilization and enjoyment of computer-based social network. Dissertation Abstracts International, 46. (UMI No. 1444827)

Merchant, G. (2012). Unravelling the social network: theory and research. Learning, Media and Technology, 37(1), 4-19.

Mondi, M., Woods, P., \& Rafi, A. (2008). A 'Uses and Gratification Expectancy Model' to predict students' 'Perceived e- Learning Experience'. Educational Technology \& Society, 11(2), 241-261.

Mujis, D., West, M., \& Ainscow, M. (2010). Why network? Theoretical perspectives on networking. School Effectiveness and School Improvement, 21(1), 5-26.

Musolesi, M., \& Mascolo, C. (2007). Designing mobility models based on social networks theory. Mobile Computing and Communications Review, 11(3), 59-70. 
Next Thing Now Report (2008, March). Universal McCann. Retrieved June 21, 2009, from http://www.scribd.com/doc/3836535/Universal-Mccann-on-Social-Media

Nyland, R., \& Near, C. (2007, February). Jesus is my friend: Religiosity as a mediating factor in Internet social networking use. Paper presented at AEJMC Midwinter Conference, Reno, NV.

Oblinger, D. \& Oblinger, J. (2005). Is it age or IT: First steps toward understanding the Net generation. In D. Oblinger, \& J. Oblinger (Eds), Educating the Net Generation, EDUCASE. Retrieved September 25, 2009, from http://net.educause.edu/ir/library/pdf/pub7101b.pdf

Osatuyi, B. (2013). Information sharing on social media sites. Computers in Human Behavior, 29(6), 2622-2631.

Palloff, R. M. \& Pratt, K. (2007). Building online learning communities: Effective strategies for the virtual classroom (2nd ed.). San Francisco: John Willey \& Sons, Inc.

Reigeluth, C. (1983). Instructional design: what is it and why is it?. In C. Reigeluth (Eds.) Instructional Design Theories and Models. New York: Lawrence Erlbaum Associates.

Rosen, C. (2007). Virtual friendship and the new narcissism. The New Atlantis, 17, 15-31.

Ruggiero, T. E. (2000). Uses and Gratifications Theory in the 21st Century. Mass Communication \& Society, 3(1), 3-37.

Sachdev, V. (2007). Why do people engage in social computing? A need fulfillment perspective. Dissertation Abstracts International, 115. (UMI No. 3307230)

Severin W. J., \& Tankard, J. W. (1997). Uses of Mass Media. In W. J. Severin, \& J. W. Tankard (Eds.) Communication Theories: Origins, Methods, and Uses in the Mass Media (4th ed.). New York: Longman.

Siemens, G. (2004, December, 12). Connectivism: A learning theory for the digital age. Retrieved January 31, 2013, from http://www.elearnspace.org/Articles/connectivism.htm

Siemens, G. (2005, August, 10). Connectivism: Learning as Network-Creation. Retrieved January 31, 2013, from http://elearnspace.org/Articles/networks.doc

Siemens, G. (2006, October). Connectivism: Learning and knowledge today. Paper presented at Global Summit 2006: Technology Connected Features, Sydney, Australia. Retrieved May 14, 2008, from http://www.educationau.edu.au/ sites/default/files/gs2006_siemens.pdf

Siemens, G. \& Tittenberger, P. (2009). Handbook for emerging technologies for learning. Retrieved July 25, 2010, from http://umanitoba.ca/learning_technologies/ cetl/HETL.pdf

Siraj, S. A. (2007). Synthesis of the structure and functions of the uses and gratification model. European Journal of Scientific Research, 17(3), 339-408.

Smock, A. D., Ellison, N. B., Lampe, C., \& Wohn, D. Y. (2011). Facebook as a toolkit: A uses and gratification approach to unbundling feature use. Computers in Human Behavior, 27(6), 2322-2329. 
Snelbecker, G. E. (1999). Some thoughts about theories, perfection, and instruction. In C. M. Reigeluth (Ed.), Instructional-design theories and models. A new paradigm of instructional theory (pp. 31-47). Mahwah, NJ: Lawrence Erlbaum Associates.

Storsul, T., Arnseth, H. C., Bucher, T., Enli, G., Hontvedt, M., Kløvstad, V. \& Maas $\varnothing$, A. (2008). New web phenomena: Government administration and the culture of sharing. Oslo University, Department of Media and Communication. Retrieved December 22, 2009, from http://www.duo.uio.no/publ/mediekomm/2008/86099/NewWebPhenomenareport.pdf

Quatman, C., \& Chelladurai, P. (2008). Social network theory and analysis: A complementary lens for inquiry. Journal of Sport Management, 22(3), 338-360.

Tinmaz, H. (2012). Social Networking Websites as an Innovative Framework for Connectivism. Contemporary Educational Technology, 3(3), 234-245.

Tschofen, C., \& Mackness, J. (2012). Connectivism and dimensions of individual experience. The International Review of Research in Open and Distance Learning, 13(1), 124-143.

Tufekci, Z. (2008). Grooming, gossip, Facebook and MySpace. Information, Communication \& Society, 11(4), 544-564.

Vie, S. (2007). Engaging others in online social networking sites: Rhetorical practices in MySpace and Facebook. Dissertation Abstracts International, 222. (UMI No. 3254886)

Vitak, J. M. (2008). Facebook "Friends": How online identities impact offline relationships. Unpublished master's thesis, Georgetown University.

Williams, M. (2008, February). Connectivism from design. Retrieved November 11, 2009, from http://design.test.olt.ubc.ca/Connectivism

Williams, R., Karousou, R., \& Mackness, J. (2011). Emergent learning and learning ecologies in web 2.0. International Review of Research in Open and Distance Learning, 12(3), 39-59.

Wise, K., Hamman, B., \& Thorson, K. (2006). Moderation, response rate, and message interactivity: Features of online communities and their effects on intent to participate. Journal of Computer-Mediated Communication, 12, 24-41.

Yang, S., Yang, X., Zhang, C., \& Spyrou, E. (2010). Using social network theory for modeling human mobility. IEEE Network: The Magazine of Global Internetworking, 24(5), 6-13. 